\title{
High nitrate, muddy estuaries as nitrogen sinks: the nitrogen budget of the River Colne estuary (United Kingdom)
}

\author{
B. Ogilvie ${ }^{1, *}$, D. B. Nedwell ${ }^{1, * *}$, R. M. Harrison ${ }^{2}$, A. Robinson ${ }^{1}$, A. Sage ${ }^{1}$ \\ ${ }^{1}$ Department of Biological \& Chemical Sciences, University of Essex, Colchester CO4 3SQ, United Kingdom \\ ${ }^{2}$ Environmental Health, School of Chemistry, University of Birmingham, Edgbaston, Birmingham B15 2TT, United Kingdom
}

\begin{abstract}
The muddy estuary of the River Colne, east coast UK, is hypernutrified, with strong gradients of $\mathrm{NO}_{3}{ }^{-}$and $\mathrm{NH}_{4}{ }^{+}$up the estuary due to inputs from the river and sewage treatment works. There were no significant transformations of nitrogen detected in the water column. In the sandy sediment at the mouth of the estuary nitrification occurred with $\mathrm{NO}_{3}{ }^{-}$export from the sediment, but the muddy sediments higher up the estuary were large sinks for $\mathrm{NO}_{3}{ }^{-}$and major sites of denitrification. The flux of $\mathrm{NO}_{3}{ }^{-}$into the sediment at these sites was correlated with the water column $\mathrm{NO}_{3}{ }^{-}$concentration, and there was a large capacity for the sediments to respond to increases in the water column $\mathrm{NO}_{3}{ }^{-}$concentration. A seasonal cycle occurred with maximum denitrification during early winter, when water column $\mathrm{NO}_{3}^{-}$was greatest and low temperatures favoured denitrification over $\mathrm{NO}_{3}^{-}$ammonification. Highest unit area rates of denitrification were measured by acetylene inhibition at the uppermost site in the estuary, but when allowance was made for the area of sediment surface in each sector the middle reaches of the estuary were more significant to the estuarine nitrogen budget. Approximately $50 \%$ of the $\mathrm{NO}_{3}{ }^{-}$flux through the estuary was denitrified during 1993-1994. In addition, measurements of denitrification by the ${ }^{15} \mathrm{NO}_{3}^{-}$jsotope pairing technique suggested that coupled nitrification-denitrification within the sediment was also important, and when this was also allowed for the sediments removed by denitrification between 18 and $27 \%$ of the total nitrogen flux through the estuary. There was some question, however, of whether the coupled nitrification-denitrification was overestimated if the anammox reaction was occurring in the highly organic, high $\mathrm{NO}_{3}{ }^{-}$sediments at the river end of the estuary. It is concluded that in these turbid, muddy estuaries the sediments are not only major attenuators of the flux of $\mathrm{NO}_{3}^{-}$, but are also very effective traps for organically bound nitrogen. This suggests that the loads of nitrogen through these estuaries to the North Sea, which are usually derived from river gauging above the high tide mark, significantly overestimate the real load as they do not take into account attenuation of nitrogen flux within the estuary. While this attenuation may decrease the nitrogen loads, it implies that any environmental impact in coastal waters may be the result of much lower loads of nitrogen than hitherto assumed.
\end{abstract}

KEY WORDS: Estuaries Eutrophication-Denitrification

\section{INTRODUCTION}

Denitrification in estuarine sediments is known to be capable of removing significant quantities of $\mathrm{NO}_{3}^{-}$ from the water column and converting them to gases (Nedwell 1975, Billen et al. 1985, Seitzinger 1988);

- Present address: WS Atkins Water Ltd, Woodcote Grove, Ashley Rd، Epsom, Surrey KT18 5BW, United Kingdom

- Addressee for correspondence. E-mail: nedwd@essex.ac.uk however, the quantitative significance of this process in attenuating the flux of nitrogen through estuaries is not well established. In some estuaries the attenuation of the nitrogen load seems to be significant (Billen et al. 1985, Seitzinger 1988, 1990), although in others it appears to be small (Nielsen et al. 1995). Balls (1994) has suggested that the degree of attenuation of $\mathrm{N}$ flux within an estuary is related to the flushing time of the estuary. The present work was undertaken from June 1992 to May 1995 to investigate the significance of 


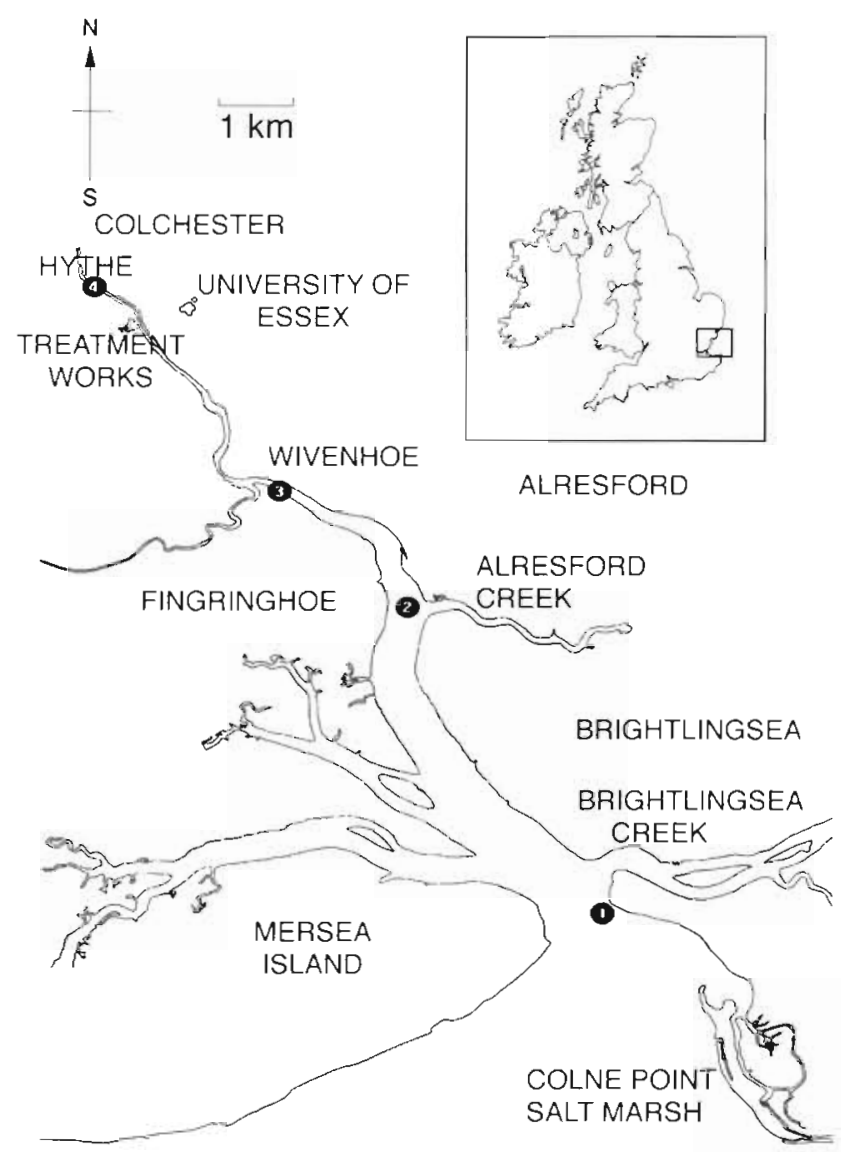

Fig. 1 Map of the Colne estuary, east coast UK, showing the positions of the 4 sampling sites

denitrification in estuarine sediments to the flux of nitrogen from land to sea. The estuary of the River Colne was selected because of the considerable body of data already available for it, the good definition of nitrogen loads into the estuary, and the relatively high $\mathrm{NO}_{3}{ }^{-}$concentrations present in the water. The estuary is typical of the hypernutrified, turbid, muddy estuaries around the southeast corner of the UK, which generally drain fertile, artificially fertilized agricultural land, and through which passes much of the load of nitrogen to the North Sea. $\mathrm{NO}_{3}{ }^{-}$is generally the dominant form of fixed nitrogen in these estuaries, at concentrations up to and above $1 \mathrm{mM}$.

\section{METHODS}

Sampling location. The Colne estuary is a small muddy macrotidal estuary (Fig. 1; 2335 ha area) on the east coast of the UK, entering the North Sea at Brightlingsea (national grid reference TM0801) The estuary catchment is $500 \mathrm{~km}^{2}$, of which the River Colne drains $300 \mathrm{~km}^{2}$, much of which is rich arable land. The estuary exhibits strong increasing gradients of both $\mathrm{NO}_{3}{ }^{-}$and $\mathrm{NH}_{4}{ }^{+}$with distance upriver in its waters (King \& Nedwell 1987) as a result of inputs from the River Colne and from sewage treatment works (STW) along the estuary. The major STW is that at the Hythe, Colchester, which accounts for $>95 \%$ of the nitrogen inputs from STW into the estuary [e.g. $25 \mathrm{Mmol} \mathrm{N}$ during 1992; Anglian Water Authority unpubl. data, National Rivers Authority (NRA) unpubl. data]. There are small STW at Fingringhoe and Brightlingsea. River inputs are gauged and concentrations analysed daily at East Gates, Colchester, by the NRA. The nutrient inputs to the estuary are therefore well defined. During summer, the river flow to the estuary is low due to water abstraction and inputs of $\mathrm{N}$ are dominated by those from the STW, of which $90 \%$ is ammonium during this period.

On the basis of preliminary surveys of nutrient concentration profiles in the water along the estuary. 4 benthic sampling sites were selected at Brightlingsea (Site 1), Alresford (Site 2), Wivenhoe (Site 3) and the Hythe, Colchester (Site 4), covering the full ranges of the estuarine nutrient gradients and sediment types along the estuary.

Sediment characteristics. Samples of sediment were taken periodically from the sites along the estuary for measurements of porosity, sediment particle size distributions by sieving, and sediment organic content with a CN analyser (model 2400, Perkin-Elmer, Beaconsfield, UK). (See Nedwell \& Trimmer 1996 for details of methods used.)

Depth of oxic layer. The depth of the surface oxic layer of sediment was measured with an $\mathrm{O}_{2}$ mesoelectrode ( $\mathrm{H}$. van Gemerden, University of Groningen, The Netherlands) (Nedwell \& Trimmer 1996). After a core had reequilibrated in an aerated bath of site water at in situ temperature for $6 \mathrm{~h}$, the electrode was introduced into the sediment surface with a micromanipulator. Measurements of dissolved $\mathrm{O}_{2}$ concentrations were made at $200 \mu \mathrm{m}$ depth intervals.

Nutrient concentrations in the water column. From April 1993 to April 1994, Periodically, full longitudinal surveys of water column nutrient concentrations were taken by boat along the estuary at both high and low tides. Samples were taken \pm 1 h of high or low water The water column of this macrotidal estuary is well mixed with no detectable stratification, and surfacewater samples were representative of the whole water column. Water samples were filtered immediately through glass fibre filters (GF/F, Whatman, UK), and analysed for the following: $\mathrm{NH}_{4}{ }^{+}$using a modification of the indophenol blue method (Harwood \& Kuhn 1970) with di-isochlorocyanurate replacing bleach as the chlorine donor (Krom 1980); $\mathrm{NO}_{3}^{-}$and $\mathrm{NO}_{2}{ }^{-}$ (Strickland \& Parsons 1972); and on 3 occasions urea 
(Price \& Harrison 1987). Water samples were also taken from all sites for measurements of benthic processes on every accasion that sediment cores were taken (see below).

Water column processes. To investigate any possible bacterial transformations of nitrogen in the water column, water samples $(20 \mathrm{ml})$ were taken at high tide from each of the 4 sites and incubated in bottles $(58 \mathrm{ml}$ volume) sealed with butyl rubber bungs, at in situ temperature in the dark. Initial $t_{0}$ concentrations of $\mathrm{NO}_{3}{ }^{-}$, $\mathrm{NO}_{2}{ }^{-}, \mathrm{NH}_{4}{ }^{+}$and $\mathrm{N}_{2} \mathrm{O}$ were measured (see previous section and below). Of 9 bottles from each site, 3 were used as controls with no additions; 3 battles had allylthiourea (ATU) solution $(200 \mu \mathrm{l}$ to give $200 \mu \mathrm{M}$ final concentration) added to inhibit $\mathrm{N}_{2} \mathrm{O}$ reduction (Hall 1984); and 3 bottles had $2 \mathrm{ml}$ of acetylene-saturated site water added to achieve a final $\mathrm{C}_{2} \mathrm{H}_{2}$ partial pressure of $10 \mathrm{kPa}$ acetylene to inhibit denitrification (Koike \& Sorensen 1988). During the $9 \mathrm{~h}$ incubation period dissolved $\mathrm{O}_{2}$ was never depleted by $>10 \%$ of air saturation. At the end of the incubation further water samples were removed from the bottles to analyse final nutrient concentrations, and net production or consumption calculated from the change in concentrations during incubation.

Sediment-water exchange of nutrients: sedimentary denitrification and $\mathrm{N}_{2} \mathrm{O}$ production. At each of the 4 sites, 12 cores of sediment $(-10 \mathrm{~cm}$ length) with overlying water $(\sim 100 \mathrm{ml})$ were taken at low tide at approximately monthly intervals between June 1993 and May 1994 from inundated sediment just below the low tide mark. The perspex core tubes $[3.4 \mathrm{~cm}$ internal diameter (i.d.) $\times 22 \mathrm{~cm}$ length] had silicon rubber-filled injection ports at $1 \mathrm{~cm}$ intervals. On return to the laboratory the water above the sediment was carefully replaced with water taken from the same site at the previous high tide, ensuring not to disturb the sediment. The cores were left to reequilibrate for $1 \mathrm{~h}$ in a water bath held at in situ temperature, and then used in experiments. The water columns were stirred with small magnetic followers $(2 \mathrm{~cm}$ length) in the middle of the water column at $120 \mathrm{rpm}$.

Three cores were used as controls with no additions; a second set of triplicate cores had ATU solution $(20 \mathrm{mM})$ injected into the water column and sediment to give a final ATU concentration of $200 \mu \mathrm{M}$; another triplicate set of cores had acetylene-saturated site water injected into both the overlying water and sediment to give a final acetylene partial pressure of $10 \mathrm{kPa}$; while a fourth triplicate set of sediment cores were used to measure initial $\mathrm{N}_{2} \mathrm{O}$ concentrations in the sediment.

The water samples removed from the water above the sediment were used to analyse concentrations of nutrients $\left(\mathrm{NH}_{4}{ }^{+}, \mathrm{NO}_{3}{ }^{-}, \mathrm{NO}_{2}^{-}\right.$, and on 3 occasions urea) at the beginning and end of the incubation periods, and hence calculate the rates of sediment-water nutrient exchange. Cores were incubated for 3 to $4 \mathrm{~h}$ in summer and 5 to $6 \mathrm{~h}$ in winter. During these periods the dissolved $\mathrm{O}_{2}$ in the water decreased $<20 \%$ of air saturation. Rates of denitrification (acetylene inhibition) were calculated from the accumulation of $\mathrm{N}_{2} \mathrm{O}$ in the presence of acetylene (see below)

$\mathrm{N}_{2} \mathrm{O}$ analysis. Bungs were inserted into core tubes and a subsample of water $(5 \mathrm{ml})$ was removed with a hypodermic syringe for nutrient analyses, introducing a $5 \mathrm{ml}$ air bubble. The core tube was then shaken vigorously to equilibrate the upper 1 to $2 \mathrm{~cm}$ of sediment and its contained $\mathrm{N}_{2} \mathrm{O}$ with the water column. [Preliminary measurements (Sage 1995, A. Robinson, D. B. Nedwell \& B. Ogilve unpubl.) had shown that $\mathrm{N}_{2} \mathrm{O}$ was present in the sediment in significant amounts only in the top $1 \mathrm{~cm}$, where active denitrification occurred.] A sample $(5 \mathrm{ml})$ of the sediment-water slurry was removed immediately with a hypodermic syringe and injected into a $12.5 \mathrm{ml}$ vacutainer (Becton Dickinson, Cowley, UK) previously flushed with $\mathrm{O}_{2}$-free $\mathrm{N}_{2}$ (OFN). Pressure within the vacutainer was equilibrated to atmospheric via a second needle while the slurry was being injected, the hypodermic needles were withdrawn, and the tubes frozen in dry ice until analyzed. Samples of laboratory air were also taken and stored in a similar manner, to act as background $\mathrm{N}_{2} \mathrm{O}$ values which were deducted from those in the samples. There was no significant loss of $\mathrm{N}_{2} \mathrm{O}$ during storage.

Subsamples of gas $(50 \mu l)$ for $\mathrm{N}_{2} \mathrm{O}$ analyses were taken from vacutainers with Pressure-Lock syringes (Alltech Ltd, Carnforth, UK) and injected into a gas chromatograph (Shimadzu GC-14A, Dyson Instruments, Houghton-le-spring, UK) equipped with a $63 \mathrm{Ni}$ electron capture detector (ECD), a 2 m glass column (3 mm i.d.) packed with Poropak Q, a carrier gas 95\% Ar:

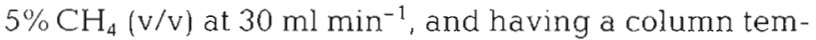
perature of $25^{\circ} \mathrm{C}$ and a detector temperature of $340^{\circ} \mathrm{C}$. The detection limit was 10 pmol $\mathrm{N}_{2} \mathrm{O}-\mathrm{N}$. When necessary, $\mathrm{N}_{2} \mathrm{O}$ was separated from $\mathrm{O}_{2}$ in samples by trapping $\mathrm{N}_{2} \mathrm{O}$ in a cold trap loop in liquid $\mathrm{N}_{2}$. After trapping, the loop was heated and $\mathrm{N}_{2} \mathrm{O}$ switched onto the $\mathrm{GC}$ column with a 6-way valve (Valco, Dyson Instruments). Acetylene can damage ECDs, and where acetylene was present in a sample as a denitrification inhibitor it was separated before entry of the GC column by a guard column packed with Poropak Q. After $\mathrm{N}_{2} \mathrm{O}$ had eluted from the guard column into the coldtrap, the flow from the guard column was switched to waste.

The analyses were calibrated with $\mathrm{N}_{2} \mathrm{O}$ standards (BOC Special Gases, London, UK) diluted in $\mathrm{He} . \mathrm{N}_{2} \mathrm{O}$ peak areas were quantified with an integrator (Shimadzu CR-6A, Dyson Instruments), and the equivalent 
dissolved concentrations calculated from the solubility coefficients of Weiss \& Price (1980) taking temperature and salinity into account.

Measurements of denitrification with ${ }^{15} \mathrm{NO}_{3}{ }^{-}$. The isotope pairing technique (Nielsen 1992, Rysgaard et al. 1995) was used to estimate sedimentary denitrification from both external $\mathrm{NO}_{3}{ }^{-}\left(D_{w}\right)$, derived by transport into the sediment from the water column, and from $\mathrm{NO}_{3}{ }^{-}$generated within the sediment by nitrification $\left(D_{n}\right)$. Cores of sediment ( 9 from each site; dimensions of core tubes and stirring were the same as for sedimentwater nutrient exchange measurements) were collected from Sites 1 and 3 on 4 occasions between August 1994 and May 1995, covering all seasons, and on 3 occasions in the same period for Sites 2 and 4 . They were returned to the laboratory $(<1 \mathrm{~h}$ ), ensuring that the sediment was not disturbed. From each set of 9 cores, 3 were used as reference cores, and 6 were supplemented with ${ }^{15} \mathrm{NO}_{3}{ }^{-}$. The water overlying the sediment of the 6 non-control cores was carefully replaced with site water, to which $\mathrm{Na}^{15} \mathrm{NO}_{3}(99.3 \%$ ${ }^{15} \mathrm{~N}$; Europa Scientific, Crewe, UK) was added to achieve an increase in $\mathrm{NO}_{3}{ }^{-}$concentration of 50 to $100 \mu \mathrm{M}$. At the 3 upstream sites this represented a $\mathrm{NO}_{3}{ }^{-}$enrichment of $\sim 15$ to $30 \%$, and at Site 1 of $-50 \%$. The water overlying the 3 reference cores was replaced with site water unamended with ${ }^{15} \mathrm{NO}_{3}{ }^{-}$. All cores were left uncapped for a pre-incubation period of approximately $1 \mathrm{~h}$, during which ${ }^{15} \mathrm{~N}$-labelled denitrification products come into equilibrium with unlabelled products (S. Rysgaard pers. comm.).

Immediately prior to the start of the incubation, $5 \mathrm{ml}$ of column water was removed from each reference core and transferred into $7 \mathrm{ml}$ bijou vials (Bibby Sterilin, Stone, UK) and immediately frozen for later nutrient analysis. The reference cores were shaken to suspend the surface 1 to $2 \mathrm{~cm}$ of sediment and a subsample of slurry $(5 \mathrm{ml})$ transferred into an Exetainer (Labco, High Wycombe, UK) to provide the initial ${ }^{14 / 1.5} \mathrm{~N}_{2}$ ratio. All other cores were fitted with bungs with suspended magnetic followers in the middle off the water column. Incubations were for 3 to $6 \mathrm{~h}$ in a water bath at in situ temperature in the dark, with gentle stirring (120 rpm) of the water columns. The dissolved $\mathrm{O}_{2}$ in the water column never decreased below $80 \%$ of air saturation. At the end of the incubation, the bung was removed and $200 \mu \mathrm{l}$ of $\mathrm{ZnCl}_{2}$ solution $(50 \%$ $w / v)$ added to the water surface. The surface of the sediment was rapidly stirred to equilibrate the upper 1 to $2 \mathrm{~cm}$ of sediment porewater with the water column. A subsample of the resultant slurry was immediately removed and dispensed into a $12.5 \mathrm{ml}$ Exetainer. A further $100 \mu l$ of $\mathrm{ZnCl}_{2}$ solution was added to the Exetainer, which was then sealed. These samples were analysed for ${ }^{28} \mathrm{~N}_{2},{ }^{29} \mathrm{~N}_{2}$ and ${ }^{30} \mathrm{~N}_{2}$ using a Europa dual inlet mass spectrometer fitted with a Europa Automatic Nitrogen and Carbon Analyser system (Europa Instruments, Crewe, UK), located in the NERI laboratory in Silkeborg, Denmark. Rates of uncoupled and coupled denitrification were calculated according to the method of Nielsen (1992).

\section{RESULTS}

\section{Sediment and oxic layer conditions}

Sediment particle size varied along the estuary, from predominantly medium sand near the estuary mouth at Site 1. (organic matter content 0.1 to $0.3 \%$ organic $\mathrm{C}$ by dry weight) to fine-grain, highly reduced silty sediments (organic content 3 to $4 \%$ ) at Sites 2 to 4 . Vertical $\mathrm{O}_{2}$ profiles in the surface sediment showed both site and seasonal differences ( $\Gamma$ ig. 2 ). There was a uecrease in the depth of the sediment oxic layer going upstream, from $>5 \mathrm{~mm}$ during winter at Site 1 , decreasing to $2.5 \mathrm{~mm}$ at Site 2 , and to 1 to $1.5 \mathrm{~mm}$ in the muddy sediments at Sites 3 and 4 . There was a distinct seasonal cycle in the depth of the oxic layer in the sandy sediments near the estuary mouth, decreasing in depth during summer when respiratory removal of $\mathrm{O}_{2}$ was high, but increasing in penetration during autumn and through to spring The muddy sediments upriver always had only a shallow oxic layer, $<2 \mathrm{~mm}$ deep, throughout the year.

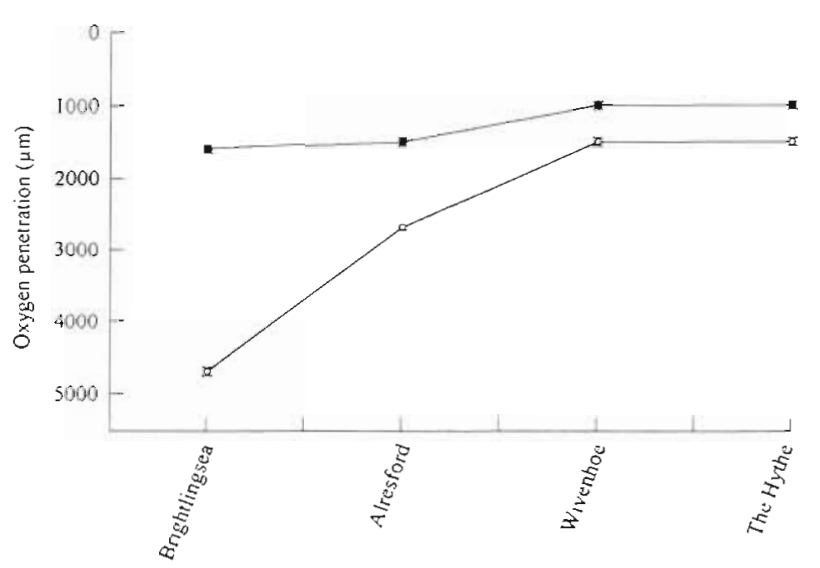

Fig. 2. Seasonal changes in the depth of the oxic layer of sediments along the estuary during winter (o: November 1993) and summer ( $\bullet$ August 1994). Bars indicate SE $(n=6)$

\section{Nutrients in the water column}

There were strong gradients of nutrients along the Colne estuary (King \& Nedwell 1987), with highest concentrations at Site 4 , where there are inputs from both 
the River Colne and the Colchester STW (Fig. 3). $\mathrm{NO}_{3}{ }^{-}$concentrations could be as high as $1200 \mu \mathrm{M}$ at Site 4 in winter. At high tide the hypernutrified water occurred only as far down the estuary as Site 2, but at low tide could be detected at Site $1 . \mathrm{NO}_{3}{ }^{-}$:salinity plots generally showed a conservative relationship over the 10 to $35 \%$ range, but were often nonlinear $<10 \%$ (data not shown). Elevated $\mathrm{NH}_{4}{ }^{+}$concentrations (Fig. 3) were also detected in the estuary, with greatest concentrations near Site 4 derived from the Colchester STW. However, $\mathrm{NH}_{4}{ }^{+}$: salinity plots along the estuary were often nonlinear, indicating more diffuse inputs of $\mathrm{NH}_{4}{ }^{+}$throughout the estuary.

\section{Processes in the water column}

Changes in water column nutrient concentrations with time were rarely significantly different from zero (ANOVA, $p>0.05$ ), either in controls or in the presence of ATU or acetylene, during incubations lasting over $9 \mathrm{~h}$. This indicated that there was no significant production or removal of $\mathrm{NH}_{4}{ }^{+}, \mathrm{NO}_{3}{ }^{-}$, $\mathrm{NO}_{2}^{-}$or $\mathrm{N}_{2} \mathrm{O}$ within the water column within the incubation period. The tidal flushing time for the estuary is $0.9 \mathrm{~d}$ (Elliot et al. 1994), and therefore bacterial nitrogen transformations within the estuarine water column are unlikely to be significant.

\section{Sediment-water exchanges}

There was consistent removal of $\mathrm{NO}_{3}{ }^{-}$by the sediment from the overlying water column during summer and early autumn at all sites (Fig. 4), with the fastest rates at Sites 3 and 4 and the slowest at Site 1 . At Site 1 , with the sandiest, most oxidized sediment, a weak $\mathrm{NO}_{3}{ }^{-}$sink changed to a strong $\mathrm{NO}_{3}{ }^{-}$output during the winter; and at Sites 1 to 3 during January there was output of $\mathrm{NO}_{3}{ }^{-}$from the sediment to water.

If the data when $\mathrm{NO}_{3}{ }^{-}$export occurred at Site 1 were omitted, there was strong correlation between the $\mathrm{NO}_{3}{ }^{-}$uptake rate by the sediments and the $\mathrm{NO}_{3}{ }^{-}$concentration in the water column. This indicated that the flux was driven by the $\mathrm{NO}_{3}{ }^{-}$concentration gradient across the sediment-water interface and that generally $\mathrm{NO}_{3}{ }^{-}$in the water column never reached saturating concentrations, but the sediments at all sites had addi- tional capacity to remove $\mathrm{NO}_{3}^{-}$from the water column. Regression equations relating $\mathrm{NO}_{3}{ }^{-}$removal to water column $\mathrm{NO}_{3}^{-}$concentration at each individual site were all statistically significant, but twice as much $\mathrm{NO}_{3}{ }^{-}$was removed per $\mu \mathrm{mol} \mathrm{NO}_{3}{ }^{-}$in the water column at Site 4 than at Site 1 . This must reflect differences in the capacities of the sedimentary micrabial communities at the 2 sites to remove $\mathrm{NO}_{3}^{-}$within the sediment and thus maintain the $\mathrm{NO}_{3}{ }^{-}$flux across the interface.

In general the sediments exported $\mathrm{NH}_{4}{ }^{+}$, the rates decreasing from Site 4 down to the mouth at Site 1 (Fig. 5). Small flux rates at Site 1 were always near zero, but at the other sites seasonal trends were apparent. At Sites 2 and 3 during winter there were minima in efflux rates, and sometimes uptake of $\mathrm{NH}_{4}{ }^{+}$from the water; however, at Site 4 there was always output of $\mathrm{NH}_{4}{ }^{+}$, which peaked during winter. The flux rates at each site were integrated with time and multiplied by the area of sediment in the water to derive an estimate of the annual flux of $\mathrm{NO}_{3}{ }^{-}$or $\mathrm{NH}_{4}{ }^{+}$(Table 1). Nitrite fluxes were undetectable, and on the 3 occasions when urea flux was examined there was no detectable export of urea. 

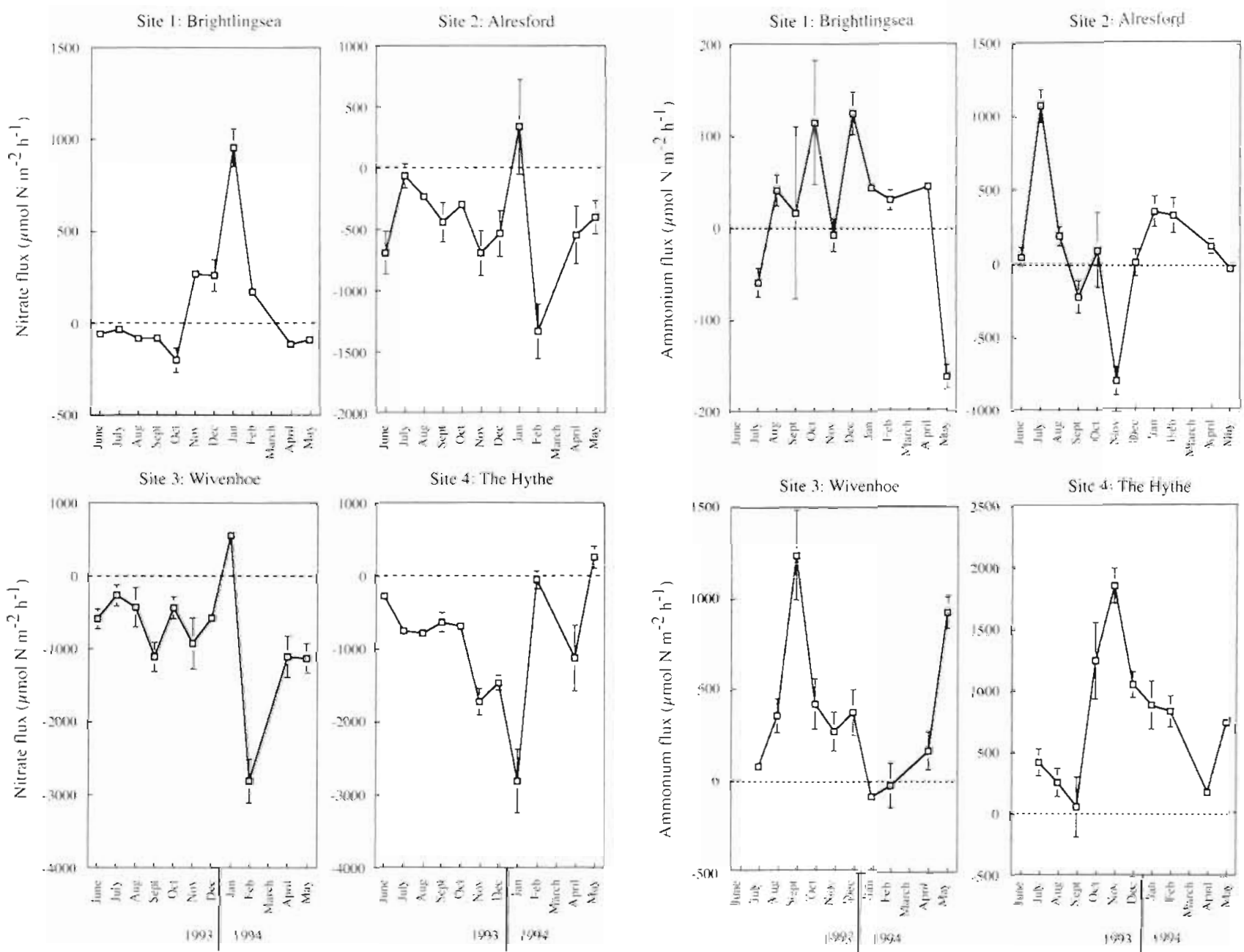

Fig. 4. Sediment-water exchange fluxes of $\mathrm{NO}_{3}{ }^{-}$along the River Colne estuary from June 1993 to May 1994. Bars indicate $\mathrm{SE}(\mathrm{n}=3)$. Negative fluxes indicate uptake of $\mathrm{NO}_{3}{ }^{-}$by the sediment from the water
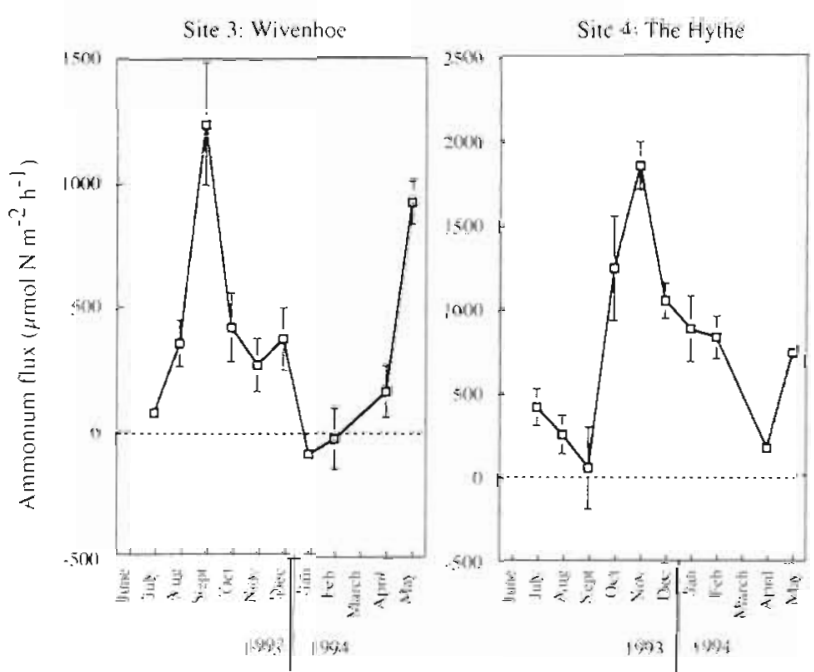

Fig. 5. Sediment water exchange fluxes of $\mathrm{NH}_{4}{ }^{+}$along the River Colne estuary from June 1993 to May 1994. Bars indicate $\mathrm{SE}(\mathrm{n}=3)$. Negative fluxes indicate uptake of $\mathrm{NH}_{4}{ }^{+}$by the sediment from the water

The presence of ATU significantly decreased the export flux of $\mathrm{NO}_{3}{ }^{-}$from Site 1 sediment in November and December 1993 and in February 1994 (but not in January), but not at other sites, suggesting the greater importance of nitrification in the sandy sediment at Brightlingsea, particularly during winter. ATU interferes with the $\mathrm{NH}_{4}{ }^{+}$assay used (Henriksen \& Kemp 1988) and no effect of ATU on $\mathrm{NH}_{4}{ }^{+}$flux could be detected. Acetylene had no statistically significant effect on the fluxes of either $\mathrm{NO}_{3}{ }^{-}$or ammonium, compared to controls.

\section{Denitrification}

The acetylene inhibition measurements (Fig. 6) showed increasing denitrification rates up the estuary,

the greatest rate being $1317 \mu \mathrm{mol} \mathrm{N} \mathrm{m}^{-2} \mathrm{~h}^{-1}$ at Site 4 in November 1993, and the lowest $19 \mu \mathrm{mol} \mathrm{N} \mathrm{m}{ }^{-2} \mathrm{~h}^{-1}$ in July 1993 at Site 1 . Rates at all sites were approximately constant during summer, increased by a factor of 2 to 4 during autumn and winter when $\mathrm{NO}_{3}{ }^{-}$loads to the estuary were high, and then returned to low values during spring. Denitrification rates measured at the beginning of June 1993 were similar to those in May 1994, indicating little interannual variability. Two-way ANOVA showed that denitrification was always significantly greater $(p<0.05)$ at the 2 upstream sites (Sites 3 and 4) than at Site 1, although there was not a significant difference between Sites 2 and 3.

Only at Site 1 were measured denitrification rates significantly correlated with water column $\mathrm{NO}_{3}{ }^{-}$concentrations $(p<0.05)$. However, when data pairs with $\mathrm{NO}_{3}{ }^{-}$concentrations $>200 \mu \mathrm{M}$ were omitted, strong 
Table 1. Mean and annual rates of exchange of $\mathrm{NO}_{3}{ }^{-}$and $\mathrm{NH}_{4}{ }^{+}$across the sediment-water interface in 4 sites and their equivalent sectors in the River Colne estuary between June 1993 and May 1994 (negative flux indicates uptake by the sedment)

\begin{tabular}{|c|c|c|c|c|}
\hline \multirow[t]{2}{*}{ Sector } & \multicolumn{2}{|c|}{$\mathrm{NO}_{3}^{-}$flux } & \multicolumn{2}{|c|}{$\mathrm{NH}_{i}^{*}$ flux } \\
\hline & $\begin{array}{l}\text { Mean rate at site } \\
\left(\mu \mathrm{mol} \mathrm{Nm}^{-2} \mathrm{~h}^{-1}\right)\end{array}$ & $\begin{array}{c}\text { Annual rate in sector } \\
\left(\mathrm{Mmol} \mathrm{N} \mathrm{yr}^{-1}\right)\end{array}$ & $\begin{array}{l}\text { Mean rate at site } \\
\left(\mu \mathrm{mol} \mathrm{N} \mathrm{m}^{-2} \mathrm{~h}^{-1}\right)\end{array}$ & $\begin{array}{c}\text { Annual rate in sector } \\
\left(\mathrm{Mmol} \mathrm{ys}^{-1}\right)\end{array}$ \\
\hline Site 1, Brightlingsea & 92.3 & 2.1 & 51.6 & 1.1 \\
\hline Site 2, Alresford Creek & -442.3 & -9.1 & 300.5 & 5.6 \\
\hline Site 3, Wivenhoe & -801.4 & -3.4 & 388.9 & 1.4 \\
\hline Site 4, Hythe & -907.8 & -1.2 & 745.4 & 1.1 \\
\hline Total & & -11.6 & & 9.2 \\
\hline
\end{tabular}

Table 2. Rates of uncoupled (U) and coupled (C) denitrification in the Colne estuary measured by isotope pairing technique. All rates are in $\mu$ mol $\mathrm{N} \mathrm{m}^{-2} \mathrm{~h}^{-1}( \pm \mathrm{SE}, \mathrm{n}=6)$

\begin{tabular}{|lcccccccc|}
\hline Month & \multicolumn{2}{c}{ Site 1, Brightlingsea } & \multicolumn{2}{c}{ Site 2, Alresford Creek } & \multicolumn{2}{c|}{ Site 3, Wivenhoe } & \multicolumn{2}{c|}{ Site 4, Hythe } \\
& U & C & U & C & U & C & U \\
\hline Aug 1994 & $40.0 \pm 4.9$ & $0.0 \pm 0.0$ & & & $164.5 \pm 16.0$ & $188.2 \pm 20.9$ & \\
Nov 1994 & $11.9 \pm 2.1$ & $14.6 \pm 2.5$ & $25.6 \pm 2.7$ & $74.2 \pm 10.7$ & $119.9 \pm 15.3$ & $63.9 \pm 6.6$ & $89.1 \pm 10.5$ & $368.7 \pm 65.1$ \\
Feb 1995 & $1.7 \pm 0.2$ & $1.5 \pm 0.5$ & $20.3 \pm 1.4$ & $82.5 \pm 15.2$ & $81.9 \pm 8.5$ & $41.9 \pm 11.9$ & $21.5 \pm 2.4$ & $66.6 \pm 13.1$ \\
May 1995 & $25.9 \pm 3.0$ & $0.0 \pm 2.5$ & $231.7 \pm 9.2$ & $9.8 \pm 9.3$ & $333.2 \pm 28.2$ & $26.7 \pm 20.7$ & $175.4 \pm 5.4$ & $185.2 \pm 32.4$ \\
Mean & 19.7 & 3.9 & 92.5 & 55.5 & 174.9 & 80.2 & 95.3 & 206.8 \\
\hline
\end{tabular}

correlations between denitrification rates and water column $\mathrm{NO}_{3}^{-}$concentrations were found at all sites. This indicated that sediment denitrification rates appeared to obey saturation kinetics, becoming $\mathrm{NO}_{3}^{-}$saturated at water column $\mathrm{NO}_{3}{ }^{-}$concentrations $>200 \mu \mathrm{M}$

\section{$\mathrm{N}_{2} \mathrm{O}$ production}

In situ $\mathrm{N}_{2} \mathrm{O}$ production rates closely followed the corresponding rates of denitrification at each site (Robinson et al. unpubl.), indicating their origin in denitrification rather than nitrification. In situ $\mathrm{N}_{2} \mathrm{O}$ production was only about $2 \%$ of the corresponding denitrification rates, implying that $>98 \%$ of the denitrification was to $\mathrm{N}_{2}$.

\section{${ }^{15} \mathrm{NO}_{3}{ }^{-}$measurements of denitrification}

Table 2 shows the results of measurements of both coupled and uncoupled denitrification at all 4 sites by the isotope pairing technique. Uncoupled denitrification $\left(D_{\mathrm{w}}\right)$ of $\mathrm{NO}_{3}{ }^{-}$from the water column showed the same trends as that measured by acetylene inhibition, with rates increasing up the estuary. However, coupled denitrification driven by $\mathrm{NO}_{3}{ }^{-}$derived from internal nitrification $\left(D_{n}\right)$ was also significant. Again, coupled denitrification increased up the estuary with the highest rates measured at Site 4 . The maximum rate of coupled denitrification at Site 1 occurred in November 1994 (14.6 $\mu \mathrm{mol}$ $\mathrm{N} \mathrm{m}^{-2} \mathrm{~h}^{-1}$, accounting for $55 \%$ of total denitrification) which corresponded with the large increase of sedimentary nitrification, detected by $\mathrm{NO}_{3}{ }^{-}$efflux, during autumn. At other times coupled denitrification was undetectable at Site 1 . On an annual basis Site 3 had

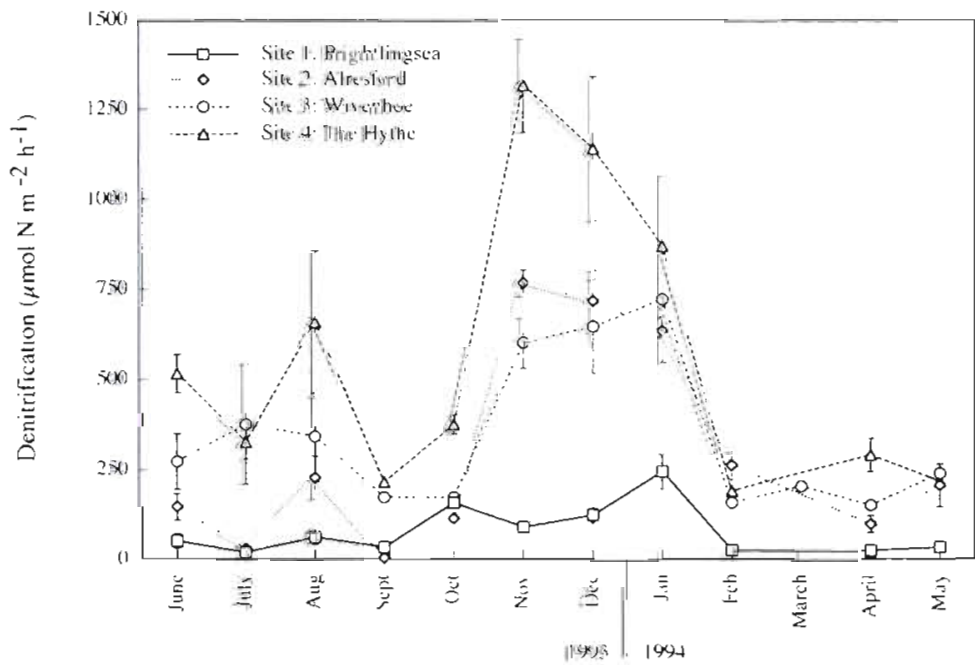

Fig. 6. Rates of denitrification (acetylene inhibition) in the sediments of the River Colne estuary from June 1993 to May 1994. Bars indıcate SE $(n=3)$ 
the greatest rate of uncoupled denitrification and Site 4 the greatest coupled denitrification (Table 2). This was somewhat surprising as Sites 3 and 4 were the 2 sites where the surface oxic layer was thinnest (Fig. 2) and where there was no other evidence for nitrification.

\section{DISCUSSION}

The sediments showed a distinct particle size gradient up the estuary, with coarser sandy sediment near the mouth where turbulence and resuspension was greatest, grading to silty muds with greater organic matter contents in the upper estuary. The changes in depth of the sedimentary oxic layer reflected this gradient, with greater $\mathrm{O}_{2}$ penetration and stronger seasonal change in the sandy sediments. There was only a very shallow oxic layer $(<2 \mathrm{~mm})$ in the muddy sediments with no seasonal change of depth.

There were always strong gradients of nutrient concentrations in the water along the estuary. Highest $\mathrm{NO}_{3}{ }^{-}$concentrations were invariably found at the 2 sites furthest upstream, due to inputs from the STW and the river. Also, $\mathrm{NO}_{3}{ }^{-}$showed distinct seasonal cycles with maximum concentrations during early winter from increased river runoff from winter rain, and from high $\mathrm{NO}_{3}{ }^{-}$in the STW, because of better nitrification at low temperature. At low tide the low salinity water with elevated nutrient concentrations smeared down the estuary as far as Site 2, so the whole reach above Site 2 could be regarded as being subjected to significant nutrient elevation. The absence of detectable changes in the concentrations of $\mathrm{NO}_{3}{ }^{-}, \mathrm{NO}_{2}$ or $\mathrm{NH}_{4}^{+}$during incubation of water samples, even in the presence of inhibitors of nitrification and denitrification, suggested that the water column was not the site of significant rates of ammonification, nitrification or denitrification. [Aerobic denitrification in the water column is a possibility that has been reported elsewhere (Lloyd et al. 1997, Robertson \& Kuenen 1990).] In addition, there was no significant increase in $\mathrm{N}_{2} \mathrm{O}$ on incubation, confirming that it was not being produced in the water column.

The measurements of sediment-water fluxes of nutrients showed that the muddy sediments were consistent sinks of $\mathrm{NO}_{3}^{-}$(Table 1), and that the rate of uptake of $\mathrm{NO}_{3}{ }^{-}$across the interface was controlled by the $\mathrm{NO}_{3}{ }^{-}$concentration in the overlying water. There was some indication that the exchange flux of $\mathrm{NO}_{3}$ became $\mathrm{NO}_{3}{ }^{-}$-saturated at concentration $>200$ to $400 \mu \mathrm{M} \mathrm{NO}_{3}{ }^{-}$, as reported elsewhere (Nedwell 1982). This is important as it emphasises that the flux of $\mathrm{NO}_{3}$ across the interface into the sediment will respond rapidly to changes (either spatial or temporal) in the $\mathrm{NO}_{3}{ }^{-}$load of the estuarine water, particularly in the middle reaches of the estuary seaward of Site 3 where water column $\mathrm{NO}_{3}$ concentrations were normally low. At Site 1 the sandy sediment was generally an exporter of $\mathrm{NO}_{3}{ }^{-}$, consistent with the apparently more aerobic sediment in which nitrification appeared to occur. There was a distinct seasonal cycle at this site with maximum $\mathrm{NO}_{3}^{-}$export occurring during the winter when there was deepest $\mathrm{O}_{2}$ penetration and increased nitrification, as reported in other sandy sediments (Billen 1975, Vanderborght \& Billen 1975). This was confirmed by the significant decrease of $\mathrm{NO}_{3}{ }^{-}$efflux from Site 1 sediment during winter in the presence of ATU. Even in the middle stretches of the estuary at Sites 2 and 3 there appeared to be greater $\mathrm{NO}_{3}$ export during January (Fig 4), consistent with greater nitrification at these sites at this time.

The sediments were generally exporters of $\mathrm{NH}_{4}{ }^{+}$ even from the sandy sediment near the estuary mouth where organic matter concentrations were smallest and nitrification greatest. The $\mathrm{NH}_{4}{ }^{+}$export from the organic sediment at Site 4 was an order of magnitude greater than at Site 1, with Sites 2 and 3 intermediate (Table 1). This was probably a function of the greater amount of organic matter present in the muddy sediments higher up the river (possibly a consequence of particulate organic matter deposition and/or higher rates of benthic algal production in the high nutrient area in the upper estuary) and higher ammonification rates in the sediment. The fluxes of $\mathrm{NO}_{2}{ }^{-}$were insignificantly small compared to $\mathrm{NO}_{3}{ }^{-}$and $\mathrm{NH}_{4}{ }^{+}$. Dissolved organic nitrogen (DON), predominantly as urea, has been reported to be a significant $\mathrm{N}$-export from some sediments, but usually only where there are abundant invertebrate populations (e.g. Boucher \& BoucherRodini 1988, Lomstein et al. 1989) or extremely high inputs of available organic matter (Lomstein et al. 1989, Pederson et al. 1993, Sloth et al. 1995). While we did not measure urea exchange fluxes routinely, it was not a detectable export from the sediments at any of the sites on the 3 occasions that it was measured. On an annual basis, except for at Site 1 the sediments were net sinks for nitrogen, with uptake of $\mathrm{NO}_{3}{ }^{-}$exceeding output of $\mathrm{NH}_{4}{ }^{+}$(Table 1). Site 3 had the greatest net removal of nitrogen from the overlying water

The measurements of denitrification by acetylene inhibition showed a gradient of sedimentary denitrification up the estuary, correlating with the greater $\mathrm{NO}$, concentrations in the water. There was a distinct seasonal cycle, with higher denitrification during early winter at all stations, even at Site 1 where denitrification during the summer was not significant. Similar winter peaks of denitrification have been reported elsewhere (Jørgensen \& Sørensen 1985, 1988, Kieskamp et al. 1991) and may be attributed to, firstly, the higher $\mathrm{NO}_{3}$ load during early winter stimulating the 
rates of sedimentary denitrification (Nedwell 1982, King \& Nedwell 1985) and, secondly, low environmental temperature, $<10^{\circ} \mathrm{C}$, increasingly selecting a denitrifying benthic microflora at the expense of $\mathrm{NO}_{3}^{-}$ ammonifiers (King \& Nedwell 1984, Herbert \& Nedwell 1990). Thus, denitrification increased markedly in the sediments during early winter, in the period of moderate low temperature, when the $\mathrm{NO}_{3}{ }^{-}$load upon the estuary was greatest due to early winter runoff The denitrification rates decreased subsequently during late winter as water column $\mathrm{NO}_{3}{ }^{-}$fell and even lower temperatures generally decreased benthic metabolic rates. Comparing the uninhibited control cores of sediment with the acetylene blocked cores showed that $\mathrm{N}_{2} \mathrm{O}$ was normally $<2 \%$ of the end-product of denitrification, the majority being $\mathrm{N}_{2}$ (Robinson et al. unpubl.).

The acetylene block method to measure denitrification has attracted criticism (Seitzinger et al. 1993). Nitrification is more sensitive than denitrification to acetylene inhibition (Hynes \& Knowles 1978, 1982, Knowles 1990) and where nitrification in the sediment is a significant source of $\mathrm{NO}_{3}{ }^{-}$, total sediment denitrification may be underestimated. The extent of this will depend upon the speed of turnover of the sedimentary $\mathrm{NO}_{3}{ }^{-}$pool relative to the incubation period of the denitrification assay. Blocking of nitrification in conjunction with a rapid turnover of the sedimentary $\mathrm{NO}_{3}{ }^{-}$pool will tend to result in the acetylene-inhibition technique measuring, specifically, denitrification from $\mathrm{NO}_{3}{ }^{-}$migrating from the water column $\left(D_{\mathrm{w}}\right)$. In the upper Colne estuary, where water column $\mathrm{NO}_{3}$ was high and the sedimentary $\mathrm{NO}_{3}{ }^{-}$pool in the surface sediment was small, the turnover time for the $\mathrm{NO}_{3}$ pool was typically $<30 \mathrm{~min}$. Secondly, $\mathrm{N}_{2} \mathrm{O}$ reductase may not be completely inhibited by acetylene, particularly when $\mathrm{NO}_{3}^{-}$concentrations are low $(<10 \mu \mathrm{M})$ and sulphide is present (Kaspar 1982, Oremland et al. 1984, Sørensen et al. 1987), leading to underestimates of $\mathrm{N}_{2} \mathrm{O}$ accumulation and therefore of denitrification. However, preliminary work indicated that $\mathrm{NO}_{3}{ }^{-}$removed from Colne sediments could be accounted for by measured accumulation of $\mathrm{NH}_{4}^{+}$and $\mathrm{N}_{2} \mathrm{O}$, indicating that the acetylene block was effective (as previously reported by King \& Nedwell 1987). In the study by Seitzinger et al. (1993) acetylene was added only to the overlying water, not injected into the sediment, so that inhibition of denitrification may have indeed been incomplete. Injection of acetylenesaturated water directly into sediment cores gives realistic rates of $D_{w}$ (Koike \& Sørensen 1988, Knowles 1990, Raymond et al. 1992, van Raaphorst et al. 1992), although it may underestimate denitrification from internally generated $\mathrm{NO}_{3}{ }^{-}$In the Colne estuary the measured denitrification rates were significantly cor-
Table 3. Denitrification in each site, and corresponding sector of the Colne estuary

\begin{tabular}{|c|c|c|}
\hline Site & $\begin{array}{l}\text { Mean denitri- } \\
\text { fication rate } \\
\left(\mu \mathrm{mol} \mathrm{N} \mathrm{m}^{-2} \mathrm{~h}^{-1}\right)\end{array}$ & $\begin{array}{c}\text { Annual rate } \\
\text { in sector } \\
\text { (Mmol } \mathrm{Mr}^{-1} \text { ) }\end{array}$ \\
\hline Site 1, Bnghtlingsea & 78.4 & 1.6 \\
\hline Site 2, Alresford Creek & 291.4 & 5.5 \\
\hline Site 3 , Wivenhoe & 352.4 & 1.3 \\
\hline Site 4 , The Hythe & 557.1 & 0.7 \\
\hline Total & & 9.1 \\
\hline
\end{tabular}

related with sedimentary $\mathrm{NO}_{3}-$ uptake rates when $\mathrm{NO}_{3}{ }^{-}$concentrations were $<200 \mu \mathrm{M}(\mathrm{p}<0.0001, \mathrm{n}=$ 27 ), and the regression coefficient was 0.63 , indicating that on average about $63 \%$ of the reduced $\mathrm{NO}_{3}$ was denitrified, the rest being presumably $\mathrm{NO}_{3}{ }^{-}$ammonified.

Estimates of total denitrification in the estuary were derived by multiplying the unit area rates of denitrification measured by acetylene inhibition at each site by the area of sediment in the sector of the river centred around that site (Table 3). Despite the very fast rates of denitrification per unit area in the high- $\mathrm{NO}_{3}{ }^{-}$upper reaches of the estuary, this sector was not the most important in gross terms due to its relatively small sediment area. The sector downstream near Site 2 was the most important as the rates of denitrification were still significant and there was a much greater sediment area than further upstream. Further seaward the total denitrification again decreased despite the even greater sediment area because of the very much smaller unit area rates of denitrification. The total estuarine denitrification rate (acetylene inhibition) on each sampling occasion was integrated with respect to time to obtain an estimate of total annual denitrification of $\mathrm{NO}_{3}{ }^{-}$from the water column $\left(D_{\mathrm{w}}\right)$ in the estuary, which was $9.1 \mathrm{Mmol} \mathrm{N} \mathrm{yr}^{-1}$. This could be compared to the total annual fluxes of nitrogen into the estuary from both river and STW inputs (18.4 $\mathrm{Mmol} \mathrm{N} \mathrm{yr}^{-1}$ from June 1993 to May 1994; data from National Rivers Authority and Anglian Water plc, respectively). Thus, denitrification of $\mathrm{NO}_{3}$ - derived from the water column in the estuary on this basis was equivalent to $49 \%$ of the annual flux of total oxidized nitrogen (TON, essentially $\mathrm{NO}_{3}{ }^{-}$).

The turnover of the $\mathrm{NO}_{3}{ }^{-}$pool in the sediment was rapid, and the sediment $\mathrm{NO}_{3}^{-}$pool was depleted relatively quickly after exposure by the tide. A more conservative estimate of estuarine $D_{w}$ would be obtained, therefore, by multiplying the unit area denitrification rate in each sector by the area of tidally immersed sediment in that sector equivalent to about $72 \%$ of the total estuarine sedimentary area. This gave an annual estimate of direct denitrification $\left(D_{w}\right)$ of $6.23 \mathrm{Mmol} \mathrm{N}$ 
$\mathrm{yr}^{-1}$, equivalent to an attenuation of $34 \%$ of the annual TON load. The range for $D_{w}$, therefore, is 34 to $49 \%$ of TON load, depending upon whether total or immersed sediment area is used. Clearly, this muddy estuary is a major attenuator of the load of $\mathrm{NO}_{3}{ }^{-}$in the estuarine water column, but this is not the only attenuation of the flux of nitrogen through the estuary.

Suspended particulate material (SPM) in estuaries tends to be greatest in the region of the turbidity maximum, at the interface between fresh and saline water (e.g. Uncles \& Stephen 1993). Settlement of SPM, including organically bound nitrogen in SPM of terrigenous origin, or that from primary production within the estuary, tends to be deposited at high water by settlement in the region of the estuarine turbidity maximum. This, together with any benthic primary production, will contribute to the high organic content of the sediments, and will be subjected to benthic organic matter mineralisation. The organically bound nitrogen will be ammonified, and then may be nitrified and denitrified. Coupled nitrification-denitrification may be sufficiently active to prevent the release of ammonium from the sediment surface (Nedwell et al. 1982) and may also be a major contributor to sedimentary denitrification (Rysgaard et al. 1995). Our measurements by the isotope pairing method (Table 2) indicated that coupled nitrification-denitrification in the Colne sediments was apparently of a similar magnitude to, and sometimes exceeded, direct denitrification. The significance of coupled nitrification-denitrification might not be surprising at Site 1, where nitrification had been shown by both $\mathrm{NO}_{3}^{-}$efflux and ATU inhibition to occur in the oxic sediment, but coupled nitrification-denitrification measured by isotope pairing was lowest at this site and apparently increased in the highly organic, reduced sediments higher up the estuary where little nitrification was suggested by other measurements. There are several possible explanations for this contradiction:

(1) Aerobic nitrification is going on at Sites 2 to 4 , but our measurements failed to detect it. It has been suggested that increased $\mathrm{NH}_{4}{ }^{+}$will stimulate nitrification rates even in sediments with very shallow oxic layers (Blackburn \& Blackburn 1992, 1993a, b). However, that conclusion was based on models with very much lower $\mathrm{NO}_{3}{ }^{-}$and $\mathrm{NH}_{4}{ }^{+}$concentrations than in the Colne estuary, where large $\mathrm{NH}_{4}{ }^{+}$effluxes from the sediments suggest that benthic nitrification is much more likely to be $\mathrm{O}_{2}$-limited than $\mathrm{NH}_{4}{ }^{*}$-limited. Sloth et al. (1995) showed that nitrification became inhibited in sediments with high organic loads, apparently because oxidation of sulphide and organic matter in the oxic layer limited the $\mathrm{O}_{2}$ available for nitrification.

(2) Nitrification in the muddy organic sediments is not aerobic autotrophic nitrification, but heterotrophic nitrification (Robertson \& Kuenen 1990), which does not apparently require $\mathrm{O}_{2}$ and which may not be detected by the conventional inhibitors of nitrification that we used

(3) The isotope pairing method is less robust than so far appreciated and the high coupled nitrificationdenitrification rates measured at Sites 2 to 4 were an artefact. Mülder et al. (1995) recently reported the enrichment isolation from estuarine sediment of Paracoccus denitrificans (formerly Thiosphaera pantotropha) which is capable of anaerobic oxidation of $\mathrm{NH}_{4}^{+}$ by $\mathrm{NO}_{3}$ respiration, during which both are converted to $\mathrm{N}_{2}$ (the anammox reaction). It might be predicted that the anammox reaction would to be favoured in anoxic sediments where there are high $\mathrm{NH}_{4}{ }^{+}$and $\mathrm{NO}_{3}$ concentrations, such as at Sites 3 and 4 . If the anammox reaction occurred in sediments when denitrification was being measured by the ${ }^{15} \mathrm{NO}_{3}{ }^{-}$isotope pairing technique, conversion of $\mathrm{NH}_{4}{ }^{+}$directly to $\mathrm{N}_{2}$, without passing through the sedimentary $\mathrm{NO}_{3}{ }^{-}$pool would result in overestimation of nitrification-denitrification $\left(D_{n}\right)$, although the total denitrification $\left(D_{n}+D_{w}\right)$ would be correctly estimated. Thus, the calculation of the attenuation of the estuarine N-load by total benthic denitrification would not be affected, although the precise mechanism by which ammonification was linked to denitrification in these organic sediments (anammox, heterotrophic nitrification, conventional nitrification-denitrification) is open to further investigation. We may note that Paracoccus denitrificans, first reported for heterotrophic nitrification, is also responsible for the anammox reaction.

The contribution of coupled nitrification-denitrification $\left(D_{\mathrm{n}}\right)$ to estuarine denitrification could be calculated in 2 ways. Firstly, it might be assumed that there was always a constant ratio between $D_{\mathrm{w}}$ and $D_{\mathrm{n}}$ despite interrannual variations in nitrogen loads to the estuary. Table 2 shows the calculation of $D_{\mathrm{w}}$ and $D_{\mathrm{n}}$ from the paired isotope techniques during 1994-1995. The calculation for $D_{w}$ used the measured average rates for each of the 4 sectors of the estuary multiplied by the immersed area of sediment and the number of days in the season $(3 \mathrm{mo})$. $D_{\mathrm{n}}$ was calculated from the total area of estuarine sediment, as coupled nitrificationdenitrification is not dependent upon tidal immersion, but will continue even after exposure. This gave a ratio of 1.13:1.0 for $D_{w}: D_{n}$ during 1994-1995. Our data set derived by acetylene inhibition measurements for $D_{w}$ during 1993-1994 was much more comprehensive than that for isotope pairing for 1994-1995, but if the same ratio for $D_{\mathrm{w}}: D_{\mathrm{n}}$ was applied this gave a value for $D_{\mathrm{n}}$ during $1993-1994$ of $5.48 \mathrm{Mmol} \mathrm{N} \mathrm{yr}^{-1}$. The total

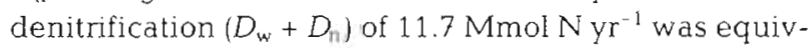
alent to $27 \%$ of the TN (total N) flux $(44.2 \mathrm{Mmol} N$ ) during the study period. Altematively, it could be 
argued that while the TON load varied from year to year with rainfall and river flow, coupled nitrificationdenitrification was a function of the organic matter content of the sediments, and therefore likely to be relatively constant on an interannual basis. The estimate for $D_{\mathrm{n}}$ during 1994-1995 could therefore be added to that for $D_{w}$ during 1993-1994, giving an estimate for total denitrification of $6.24+1.85=8.08 \mathrm{Mmol} \mathrm{N} \mathrm{yr}^{-1}$, or $18 \%$ of the TN load during the study period. This gives a range of attenuation by total denitrification $\left(D_{\mathrm{w}}+D_{\mathrm{n}}\right)$ of 18 to $27 \%$ of the TN load into the estuary. This estimate assumes that all the major inputs of nitrogen to the estuary are known. Atmospheric deposition of nitrogen within the estuary will be insignificant compared to other inputs, and $\mathrm{N}_{2}$ fixation, particularly in estuaries with elevated nitrogen concentrations where nitrogenase is inhibited, is assumed to be negligible (Capone 1983, 1988, Seitzinger 1988).

Our data would indicate that coupled and direct denitrification would together lead to about a 20 to $30 \%$ reduction of the total nitrogen flux in the Colne estuary before it reaches the North Sea. If this attenuation factor is typical of all muddy estuaries, it means that nitrogen loads to coastal seas (which are estimated from river gauging above the tidal limit) have been overestimated, and the actual loads are considerably less. This does not mean that even greater estuarine nitrogen loadings can be tolerated, as any effects of eutrophication in coastal waters may have been caused by less than the assumed nutrient load. Other workers have estimated high attenuation of nitrogen (Billen et al. 1985, Seitzinger 1988, 1990) similar to that in the Colne, although in other estuaries where $\mathrm{N}$ loads are lower, attenuation appears to be smaller (Nielsen et al. 1995). The degree of attenuation of the estuarine nitrogen flux will depend at least in part on the flushing time of the estuary (Balls 1994); longer residence times give greater potential for attenuation by the sediments of nitrogen fluxes. The River Colne is considered to be macrotidal (Burrell et al. 1993) and has a comparatively rapid tidal flushing time of $0.9 \mathrm{~d}$ (Elliot et al. 1994). Other muddy turbid estuaries around the southern North Sea drain rich catchments and have high nutrient concentrations with longer flushing times than the Colne. These estuaries may have even greater attenuation of the estuarine $N$ load and act as significant nutrient buffers between the land and sea, their sediments trapping both soluble and settled particulate nitrogen from the estuarine water column and channelling it into denitrification and loss from the estuary to the atmosphere as gases. There may be other consequences of this gaseous loss to the atmosphere, however, which are less environmentally beneficial (Robinson et al. unpubl.).
Acknowledgement. This work was funded by a Research Grant (GR3/8172A) to D.B.N. and R.M.H. by the Natural Environment Research Council, UK.

\section{LITERATURE CITED}

Balls PW (1994) Nutrient unputs to estuaries from nine Scottish East Coast rivers: influence of estuarine processes on inputs to the North Sea. Estuar Coast Shelf Sci 39:329-352

Bıllen G (1975) Nitrification in the Scheldt estuary (Belgium and the Netherlands). Estuar Coast Mar Sci 3:79-89

Billen G, Somville M, de Becker E, Servais P (1985) A nitrogen budget of the Scheldt hydrographical basin. Neth $J$ Sea Res 19:223-230

Blackburn TH, Blackburn ND (1992) Model of nitrification and denitrification in marine sediments. FEMS Microbiol Lett 100:517-522

Blackburn TH, Blackburn ND (1993a) Coupling of cycles and global sıgnificance of sediment diagenesis. Mar Geol 113: $101-110$

Blackburn TH, Blackburn ND (1993b) Rates of microbial processes in sediments. Phil Trans R Soc Lond Ser A 344 : $49-58$

Boucher G, Boucher-Rodini R (1988) In situ measurements of respiratory metabolism and nitrogen fluxes at the interface of oyster beds. Mar Ecol Prog Ser 44:229-238

Burrell GKL, McArthur Cl, Johnson MW (1993) A review of the quality and status of the Suffolk and Essex estuaries and coastal waters. National Rivers Authority, Anglian Region, Ipswich

Capone DG (1983) Benthıc nitrogen fixation. In: Carpenter EJ, Capone DG (eds) Nitrogen in the marine environment. Academic Press, New York, p 105-137

Capone DG (1988) Benthic nitrogen fixation. ln: Blackburn TH, Surensen J (eds) Nitrogen cycling in coastal marine environments. SCOPE 33, Wiley, Chichester, p 85-114

Elliot M, De Jonge VN, Burrell KL, Johnson MW, Phillips GL, Turner TM (1994) Trophic status of the Ore/Alde, Deben, Stour and Colne estuaries. Report to the National Rivers Authority, UK, University of Hull

Hall GH (1984) Measurement of nitrification rates in lake sediments: comparison of the nitrification inhibitors nitrapyrun and allylthiourea. Microb Ecol 10:25-36

Harwood JE, Kuhn AL (1970) A colorimetric method for ammonia in natural waters. Water Res 4:805-811

Henriksen K, Kemp WM (1988) Nitrification in estuarine and coastal marine sediments: methods, patterns and regulating factors. In: Blackburn TH, Sorensen J (eds) Nitrogen cycling in coastal marine environments. John Wiley \& Sons, New York, p 201-249

Herbert RA, Nedwell DB (1990) Role of environmental factors in regulatıng nitrate respiration in intertidal sediments. In: Revsbech NP, Sorensen J (eds) Denitrification in soil and sedıment. Plenum Press, New York, p 77-90

Hynes RK, Knowles R (1978) Inhibition by acetylene of ammonia oxidation in Nitrosomonas europeaea. FEMS Microbiol Lett 4:319-321

Hynes RK, Knowles R (1982) Effect of acetylene on autotrophic and heterotrophic nitrification. Can J Microbiol 28: $334-340$

Jørgensen BB, Sorensen J (1985) Seasonal cycles of $\mathrm{O}_{2}, \mathrm{NO}_{3}$ and $\mathrm{SO}_{4}{ }^{2-}$ reduction in estuarine sediments: the significance of an $\mathrm{NO}_{3}{ }^{-}$reduction maximum in spring. Mar Ecol Prog Ser 24:65-74

Jorgensen KS, Sørensen J (1988) Two annual maxima of nitrate reduction and denitrification in estuarine sedi- 
ments (Norsminde Fjord, Denmark). Mar. Ecol Prog Ser 48 $147-154$

Kaspar HF (1982) Denitrification in marine sediment: measurement of capacity and estimate of in situ rate. Appl Environ Microbiol 43:522-527

Kieskamp WM, Lohse L, Epping E. Helder W (1991) Seasonal variation in denitrification rates and nitrous oxide fluxes in intertidal sediments of the westem Wadden Sea. Mar Ecol Prog Ser 72:145-151

King D, Nedwell DB (1984) Changes in the nitrate-reducing community of an anaerobic saltmarsh sediment in response to seasonal selection by temperature. J Gen Microbiol 130:2935-2941

King D, Nedwell DB (1985) The influence of nitrate concentration upon the end-products of nitrate dissimilation by bacteria in anoxic saltmarsh sediment. FEMS Microbiol Ecol. 31:23-28

King D, Nedwell DB (1987) The adaptation of nitrate-reducing bacterial communities in estuanne sediments in response to overlying nitrate load. FEMS Microbiol Ecol 45:15-20

Knowles (1990) Acetylene inhibition technique: development, advantages and potential problems. In: Revsbech NP, Sorensen J (eds) Denitrification in soil and sediment. Plenum Press, New York, p 151-166

Koike I, Sørensen J (1988) Nitrate reduction and dentrification in marine sediments. In: Blackburn TH, Sorensen J (eds) Nitrogen cycling in coastal manne environments. John Wiley \& Sons, New York, p 251-273

Krom MJD (1980) Spectrophotometric determination of ammonia: a study of modified Berthelot reaction using salicylate and dichloroisocyanurate. The Analyst 105: $305-317$

Lloyd D, Boddy L, Davies KJP (1987) Persistence of bacterial denitrification capacity under aerobic conditions: the rule rather than the exception. FEMS Microbiol Ecol 45:185-190

Lomstein BA, Blackburn TH, Henriksen K (1989) Aspects of the nitrogen and carbon cycling in the northern Bering Shelf sediment. I. The significance of urea turnover in the mineralization of $\mathrm{NH}_{4}{ }^{+}$. Mar Ecol Prog Ser 57:237-247

Mülder A, van de Graaf AA, Robertson LA, Kuenen JG (1995) Anaerobic ammonium oxidation discovered in a denitrifying fluidized bed reactor. FEMS Microbiol Ecol 16: $177-184$

Nedwell DB (1975) Inorganic nitrogen metabolism in a eutrophicated tropical estuary. Water Res 9:221-231

Nedweli DB (1982) Exchange of nitrate, and the products of bacterial nitrate reduction, between seawater and sediment from a UK saltmarsh. Estuar Coast Shelf Sci 14 : $557-566$

Nedwell DB, Hall SE, Andersson A, Hagström ÁF, Lindström $E B$ (1982) Seasonal changes in the distribution and exchange of inorganic nitrogen between sediment and water in the northern Baltic (Gulf of Bothnia). Estuar Coast Shelf Sci 17:169-179

Nedwell DB. Trimmer M (1996) Nitrogen fluxes through the upper estuary of the Great Ouse, England: the role of the bottom sediments. Mar Ecol Prog Ser 142:273-286

Nielsen K, Nielsen LP, Rasmussen P (1995) Estuarine nitrogen retention independently estimated by the denitrification rate and mass balance methods: a study of Norsminde Fjord, Denmark. Mar Ecol Prog Ser 119:275-283
Nielsen LP (1992) Denitrification in sediment determined from nitrogen isotope pairing. FEMS Microbiol Ecol 86 : $357-362$

Oremland RM, Umberger C, Culbertson CW, Smith RL (1984) Denitrification in San Ffancisco Bay intertidal sediments. Appl Environ Microbiol 47:1106-1112

Pedersen H, Lomstein BA, Blackburn TH (1993) Evidence for bacterial urea production in marine sediments. FEMS Microbiol Ecol 12:51-59

Price NM, Harrison PJ (1987) Comparison of methods for the analysis of dissolved urea in seawater. Mar Biol 94: $307-317$

Raymond N, Bonin P, Bertrand JC (1992) Comparison of methods for measuring denitrifying activity in marine sediments from the western Mediterranean coast. Oceanol. Acta 15:137-143

Robertson LA, Kuenen JG (1990) Physiological and ecological aspects of aerobic denitrification, a link with heterotrophic nitrification? In: Revsbech NP. Sorensen J (eds) Denitrification in soil and sediment. Plenum Press, New York, p 91-104

Rysgaard S, Christensen PB, Nielsen LP (1995) Seasonal variation in nitrification and denitrification in estuarine sediment colonized by benthic microalgae and bioturbating infauna. Mar Ecol Prog Ser 126:111-121

Sage AS (1995) Removal of nitrate from estuarme water and its reduction in the bottom sediments. PhD thesis, University of Essex

Seitzinger SP (1988) Denitrification in freshwater and marine ecosystems; ecological and geochemical significance. Limnol Oceanogr 33:702-724

Seitzinger SP (1990) Denitrification in aquatic sediments. [n: Revsbech NP, Sorensen J (eds) Denitrification in soil and sedirnent. Plenum Press, New York, p 301-322

Seitzinger SP, Nielsen LP, Caffrey J, Christensen PB (1993) Denitrification measurement in aquatic sediments: $a$ comparison of three methods. Biogeochemistry 23: $147-167$

Sloth NP. Blackburn TH, Hansen LS, Risgaard-Petersen N, Lomstein BA (1995) Nitrogen cycling in sediments with different organic loading. Mar Ecol Prog Ser 11.6:163-170

Sørensen J, Rasmussen LK, Koike I (1987) Micromolar sulfide concentrations alleviate acetylene blockage of nitrous oxide reduction by denitrifying $P_{\text {seudomonas fluorescens. }}$ Can J Microbiol 33:1001-1005

Strickland JDH, Parsons TR (1972) A practıcal handbook of seawater analysis. Fisheries Research Board of Canada, Otfawa

Uncles RJ, Stephens JA (1993) Nature of the turbidity maximum in the Tamar estuary, UK. Estuar Coast Shelf Sci 36 $413-431$

Vanderborght JP, Billen G (1975) Vertical distribution of nitrate concentration in interstitial water of marine sediments with nitrification and denitrification. Limnol Oceanogr 20:953-961

van Raaphorst W, Kloosterhuis HT, Berghuis EM. Gieles AJM, Malschaert JFP, van Noort GJ (1992) Nitrogen cycling in two types of sediments of the southern North Sea (Frisian Front, Broad Fourteens): field data and mesocosm results. Neth J Sea Res 28:293-316

Weiss RF, Price BA $\{1980)$ Nitrous oxide solubility in seawater. Mar Chem 8:347-359

Manusctipt first received: July 22, 1996

Revised version accepted: Fehruary 27, 1997 